\title{
POINT-LOAD TEST ASSESMENT AS STUDY OF ADOBE BUILDINGS DAMAGED AFTER THE 2017 PUEBLA EARTHQUAKE
}

\author{
A SANCHEZ ${ }^{1 *}$, E. M. ALONSO ${ }^{1,2}$ AND J. A. BEDOLLA ${ }^{3}$ \\ ${ }^{1}$ Programa Interinstitucional de Doctorado en Arquitectura \\ Faculty of Architecture, Universidad Michoacana San Nicolás de Hidalgo \\ Gral. Francisco J. Múgica S/N, 58040 Morelia, Michoacán, México \\ e-mail: adria.sanchez.9@hotmail.com \\ ${ }^{2}$ Materials Department, Faculty of Civil Engineering, Universidad Michoacana San Nicolás de \\ Hidalgo,Gral. Francisco J. Múgica S/N, 58040 Morelia, Michoacán, México \\ email: eliamercedesalonso@gmail.com \\ ${ }^{3}$ Faculty of Architecture, Universidad Michoacana San Nicolás de Hidalgo \\ Gral. Francisco J. Múgica S/N, 58040 Morelia, Michoacán, México \\ email: bedollaalberto@gmail.com
}

Keywords: Adobe Masonry, Point-load test, Vernacular architecture, Seismic affectation

\begin{abstract}
The 2017 Puebla Earthquake on September 19 struck a big part of Mexico causing the loss of historic buildings in several states, being the state of Morelos one of the most damaged in the whole country. Jojutla de Juarez was the most affected locality of Morelos presenting important structural damages or total collapse in the built heritage, being the traditional earthen buildings, made of adobe bricks, the most vulnerable buildings to seismic efforts.

Some of the causes which contributed to the poor behaviour of the buildings were the improper handling of the constructive systems and materials, the insufficient resistance of the structures and the problems derivate by the foundations. The adobe houses of Jojutla presented a mixture between the traditional building techniques and industrial materials like concrete, bricks, blocks and steel; also with irregular heights and plant layouts and inadequate connections between the walls and foundations and roofs, resulting into a higher seismic vulnerability when the earthquake impacted. Also the adobe bricks presented irregularities in its composition and use of additives which resulted in completely different typologies and the loss of the traditional construction techniques.

There was conducted a study to determine the earthquake resistance of the adobe bricks of the houses in Jojutla, considering that the remaining structures were severely damaged and a whole study of the seismic vulnerability would not be possible due the loss of the physical buildings. The granulometry and composition of the adobe samples of the buildings were determined as well as the natural aggregates like straw and its proportion. Also the compressive strength of the pieces was tested by two methods: the compression test and the point-load test, in order to obtain the indicative values which could be compared with other patrimonial and vernacular study cases.
\end{abstract}


It was observed that the construction materials and therefore the adobe bricks of Jojutla presented different compositions which caused an unpredictable behaviour during the earthquake of September $19^{\text {th }}$. Loss of the traditional earthen construction techniques has provoked a poor manufacture of the adobe houses, creating new scenarios where people do not trust in the material and substitutes the earthen architecture by modern materials. The conduction of point-load tests in situ could be an alternative to study the mechanical properties of patrimonial samples before its disappearance.

\section{INTRODUCTION}

México is a country with an important seismic history, experiencing recurrently huge earthquakes of great magnitude which have big impact in its population. The nearest states to the Trans-Mexican Volcanic Belt, the Cocos Plate, the Rivera Plate and Pacific Plate, present high seismic hazards, being prone to experiment earthquakes which cause acute damages in the cultural heritage. In the month of September of 2017 the country suffered two big seismic events which had an enormous impact on the affected regions.

The first earthquake struck on September $7^{\text {th }}$ of 2017 in the Gulf of Tehuantepec, near the Mexican state of Chiapas, with a magnitude of 8.2 Richter magnitude scale, being originated in the Cocos Plate. This natural disaster was marked by the multiple aftershocks which were detected on the following days, causing damages mainly in Chiapas and Oaxaca [1]. On the other hand, the second earthquake was reported by the Servicio Sismológico Nacional of

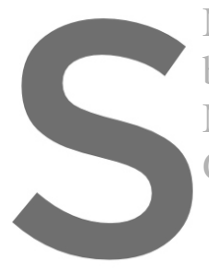
México on September boundaries between the Morelos [2]. In this case, Guerrero and Mexico
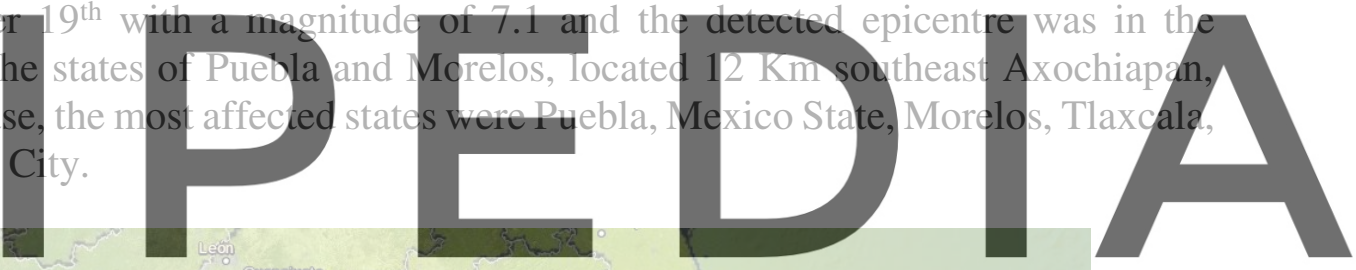

Register for free at https//www.scipedia.com to download the version without the watermark

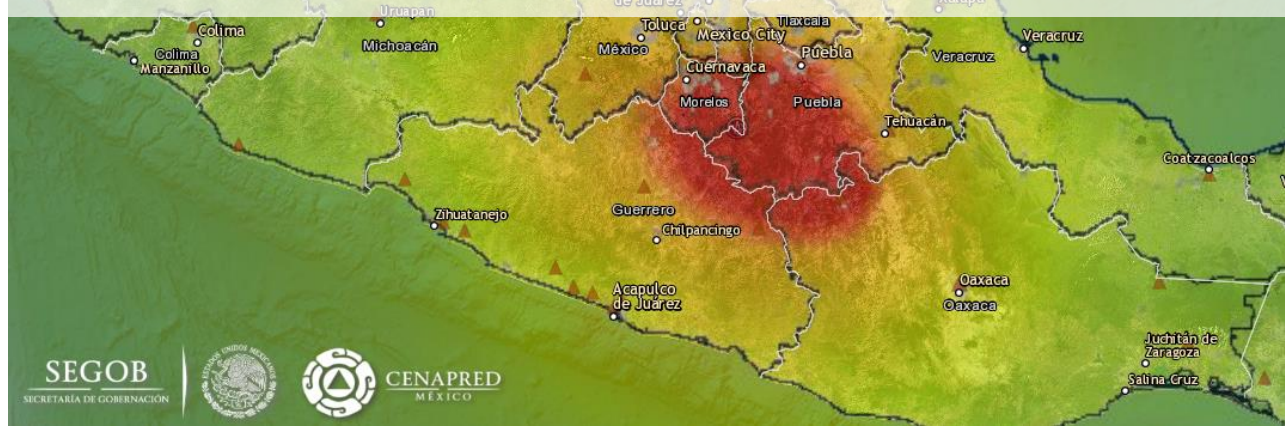

Figure 1: Seismic intensity map of the 2017 Puebla Earquake. Source: Atlas Nacional de Riesgos, map generated by Earthquake Institute of the National Autonomous University of México (UNAM)

The impact of the 2017 Puebla Earthquake on the region was especially destructive for the colonial buildings which are part of the Mexican cultural heritage, resulting in severe damages mainly in the states of Puebla and Morelos. In Morelos, the National Institute of Anthropology 
and History (INAH) ${ }^{1}$ reported a total number of 259 buildings affected, suffering damages classified as severe in the $47 \%$ of the whole ensemble [3]. The study case of Jojutla de Juarez, was the most affected locality of Morelos presenting important structural damages or total collapse in the built heritage, being the traditional earthen buildings, made of adobe bricks, the most vulnerable buildings to seismic efforts (See Fig. 2).

\subsection{Background}

Despite the great impact of these events, the seismic memory of the population is short, the state of alert only remains for a short period of time following the earthquake, disappearing gradually, as the disaster ceases to seem an immediate danger [4]. In the study case of the State of Morelos, the closest seismic events which had a deep impact in the society were the 1985 Mexico City earthquake and the 1999 Tehuacan or Central Mexico earthquake, with meaningful consequences on the architectonic and cultural heritage of the region; however these two remained distant in the collective memory of the population [5].

The destructive effect in the architectonic and cultural heritage was translated into the physical destruction of the buildings and monuments, being especially remarkable the damages in the Mexican colonial churches, which are very significant elements for the local culture and the identity of the communities [5]. Due to the importance of these constructions, the damages were analysed, full-filling appropriate research jobs to understand the seismic response of these structures [6].
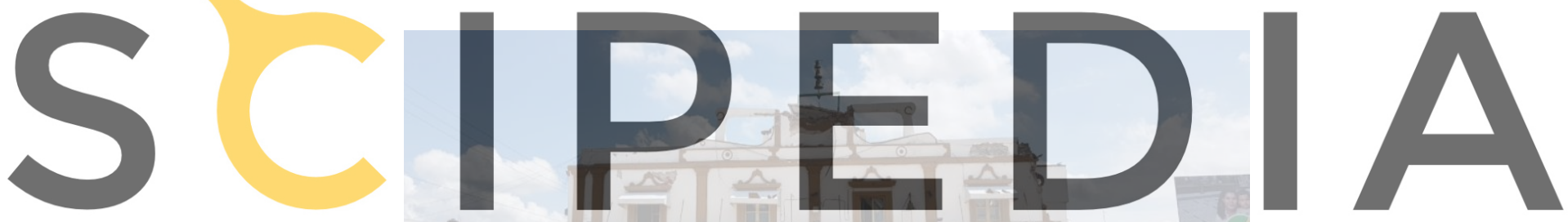

Register for free at https//www.scipedia.com to download the version without the watermark

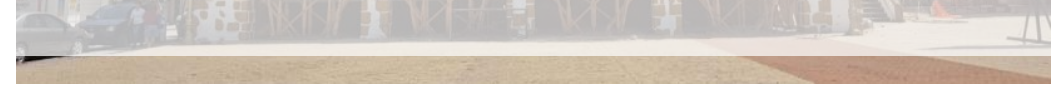

Figure 2: Municipality of Jojutla de Juárez after the 2017 Puebla Earthquake

Nonetheless, despite the reconstruction and restoration work done by the authorities and responsible entities, the traditional housing, in particular the typologies with adobe walls, were ignored. The resources were invested in the restoration of the ancient churches and monuments and the rehabilitation of homes and public structures as well as the building of new housing with modern materials. Notwithstanding the great consequences for the vernacular architecture, the organisations in charge decided not to support this local culture, appraising adobe bricks as an unsafe material [7]. The result of these disputed resolutions turned into the abandonment of the traditional techniques and the reconstruction of the localities of the region with prefabricated concrete blocks and ceramic brick walls and roof structures of metal casing.

\footnotetext{
1 The INAH, Instituto Nacional de Antropología e Historia, is the Mexican federal government bureau established in 1939 to guarantee the research, preservation, protection, and promotion of the prehistoric, archaeological, anthropological, historical and paleontological heritage of México.
} 


\subsection{Case study}

The state of Morelos has a strong adobe building tradition which can be observed from tis vernacular architecture, being the adobe housing one of the most representative typologies found. This architecture has resisted over time, withstanding important natural disasters. Most of these traditional structures present earthquake-resistant features through several properties in the materials, form, dimensions and functionality of the buildings [8]. These earthen constructions have suffered over time the struck of historic earthquakes which had a big impact on the built heritage, withstanding thanks to the qualities of the local architecture.

In the study case of Jojutla de Juarez, the traditional adobe houses of the locality were fairly modified over the years, changing the ancient materials and construction systems for modern ones; the vast majority of the buildings had important alterations to its morphology too. Besides, the conservation and maintenance of the constructions were precarious, as a result of the lack of knowledge and interest of the vernacular technologies, which always responded to the natural environment [9]. On the other hand, the traditional houses which conserved their morphology, dimensions, materials and techniques; had a better performance agains the 2017 Puebla earthquake, suffering non significant damages, as it has been demonstrated in posterior research works [7] [10].

Jojutla de Juarez shown a micro-seismic-regionalisation, especially in some of its colonies or neighborhoods. The historic centre of the town was widely damaged, suffering important losses in the built heritage, like the churches and main institutions, as well as public housing.
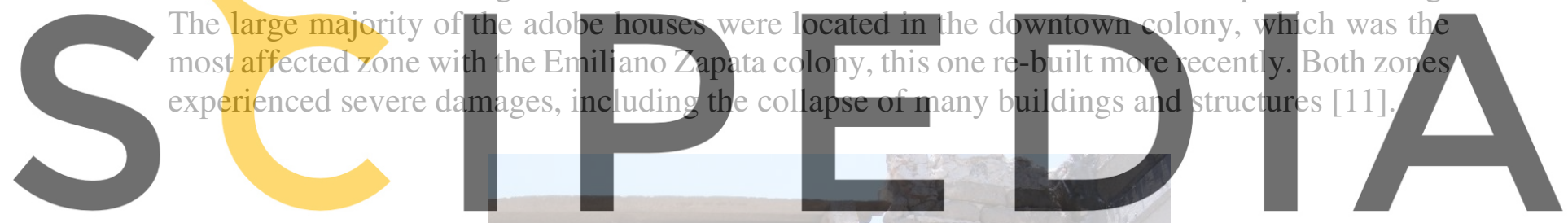

Register for free at https//www.scipedia.com to download the version without the watermark

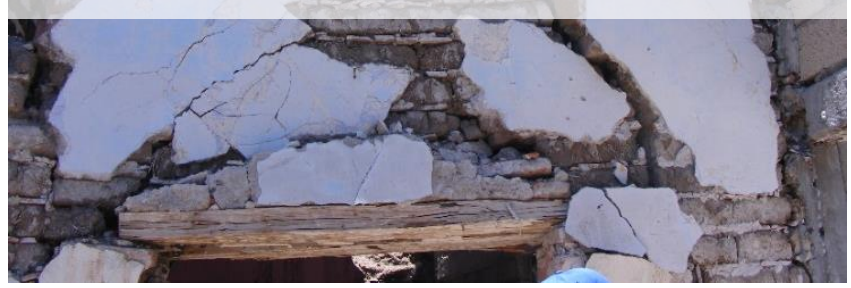

Figure 3: Damaged adobe building with mixed construction techniques

\section{METHODOLOGY}

In order to study the seismic disaster affectation on the adobe buildings of Jojutla de Juárez, several samples were collected to work with them. Considering that the remaining structures were severely damaged and a whole study of the seismic vulnerability would not be convenient due the loss of the traditional buildings, it was decided to apply compressive strength and pointload tests in order to obtain the indicative values of mechanical resistance, which could be compared to other patrimonial and vernacular study cases. 


\subsection{Sampling adobe and soil}

There were collected 11 representative shards of adobe bricks from 11 different traditional houses in the downtown of Jojutla. These samples were collected before the demolition of the buildings, which was shortly after the field trip in May 2018. There also were taken samples of quarry soils of the region, concretely in the extraction area for the manufacture of adobe bricks and ceramic bricks. The region is recognized by their rice production, even the Morelos rice is a trade mark, and of course they have plenty of water. Taking into account the emergency state of Jojutla de Juarez and the situation between the inhabitants and their damaged buildings, the sample collection responded to the criteria of taking the maximum permissible amount possible of material before the demolition of the remaining houses and the consequently disappearing of the earthen architecture. All the samples were classified by the Unified Soil Classification System (USCS) to obtain the composition of the adobe bricks and the type of soils used for construction materials in the region. There was also obtained the fibre percentage, straw in the case of study, in each one of the adobes.

\subsection{Compressive strength test}

In order to performance the compressive strength of the samples, these had to be prepared. Due to their precarious state, most of them were found between the building remains of Jojutla de Juarez, not all the original samples qualified for the compression strength test, as they didn't accomplish the minimum dimensions or were extremely inconsistent. From the 11 patrimonial samples only 6 could be preparation. For bein appropriate dimensions, in their surface. Once Machine to obtain their
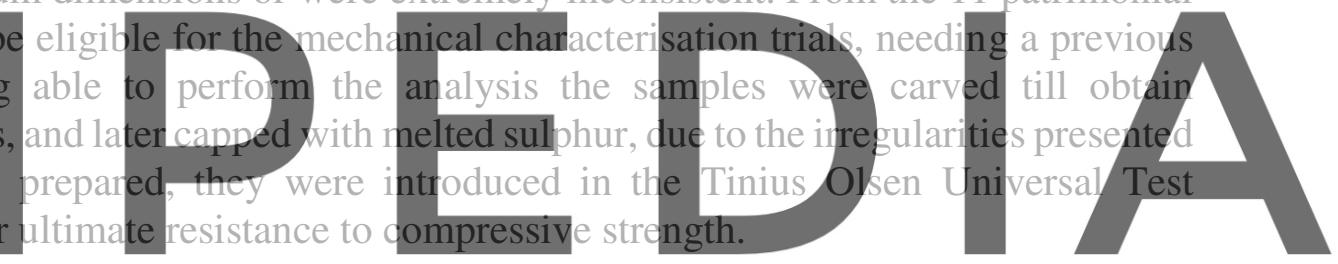

Register for free at https//www.scipedia.com to download the version without the watermark
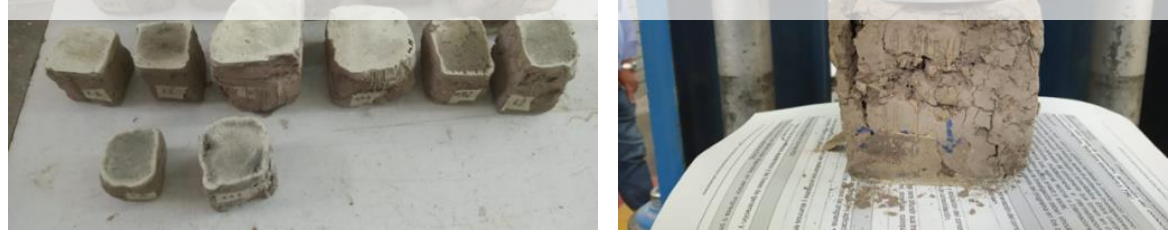

Figure 4: Preparation and compressive testing of the adobe samples

\subsection{Point-load test}

Point-load test allows determining mechanical resistance of non-carved samples of several types of masonries and rocks, both: natural or artificial, being especially designated for the study of rocks [12]. The first research works which utilised the test achieved to associate the uniaxial compressive resistance with the point-load index (Is), creating the basis to apply the analysis to rock fragments [13]. Nevertheless, the materials researched in this work are adobe bricks, being a first approximation to the characterisation of solid clay fragments with this technique. 
The equipment used for the point-load test was Digital rock strength index apparatus $100 \mathrm{kN}$ cap of Controls Group, which has the advantage of being a portable equipment which allows to test samples both in the laboratory or in field research, with the only preparation of the measurement of each one of the fragments before performing the test.

The samples were tested under Compression strength, after cracking; the fragments were also submitted to point-load test applying an incremental load leading to the failure of the fragments, to compare the data. The equipment gave a rupture load value which needed to be transformed by an equation system to the ultimate unconfined uniaxial compression resistance. The methodology followed was according the ASTM standards and previous research works performed in the materials laboratory [12, 14-15].
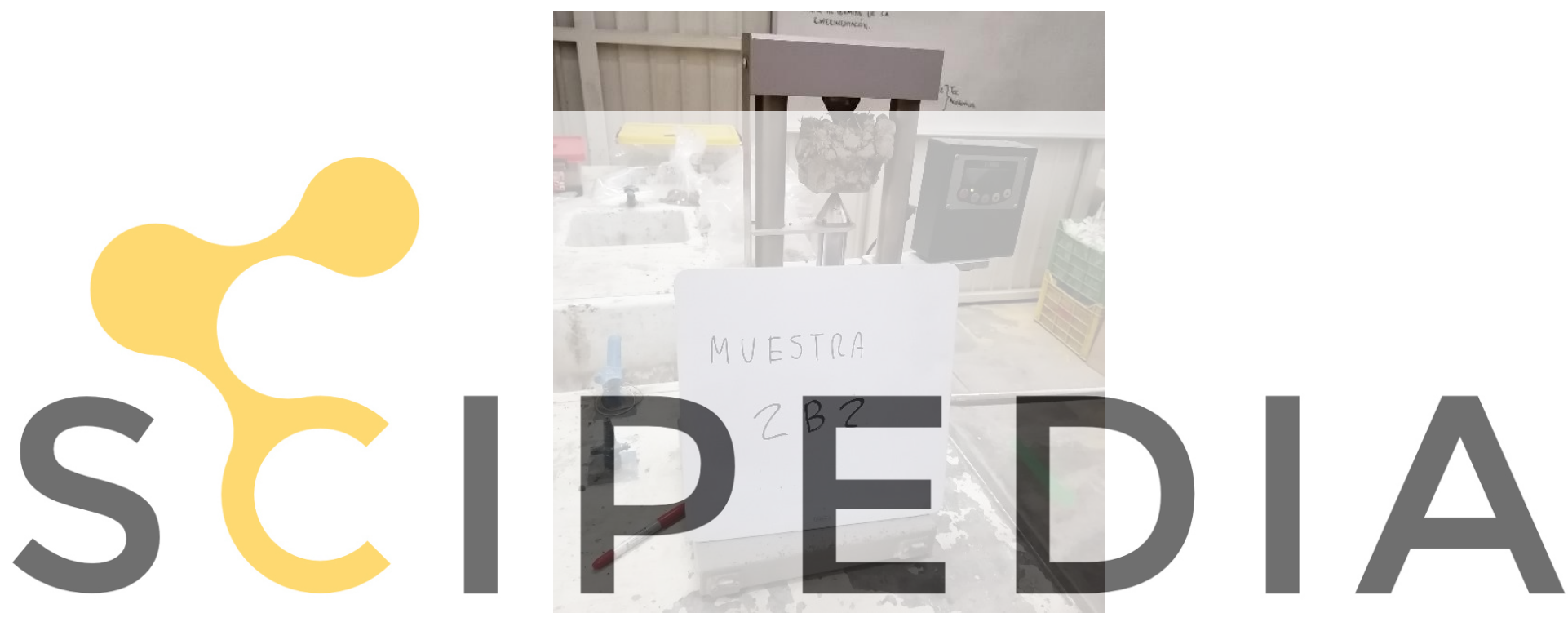

Figure 5: Adobe sample in the point-load equipment

Register for free at https//www.scipedia.com to download the version without the watermark

The point-load index without correction factor is calculated with the following equation:

$$
I_{s}=\frac{P * 1000}{D_{e}^{2}}
$$

Where:

$\mathrm{I}^{\mathrm{s}}=$ Point-load index, $\mathrm{MPa}$.

$\mathrm{P}=$ Maximum load, $\mathrm{kN}$.

$\mathrm{De}=$ Equivalent core diameter, $\mathrm{mm}$.

The resistance index value $\left(I_{S}\right)$ is a non-corrected value which varies depending on the thickness of the fragments tested. To obtain the corrected resistance index $\left(I_{S(50)}\right)$ it is necessary to multiply the first index by the correction factor:

$$
I_{S(50)}=F * I_{S}
$$

Depending on the size of the fragments, there will be used two different correction factors. The election between one or other will be the proximity of each sample to the standard value of $50 \mathrm{~mm}$ [12]. For the specimens near to this $50 \mathrm{~mm}$ thickness (D), the correction factor is calculated with the following equation: 


$$
F=\sqrt{\left(\frac{D_{e}}{50}\right)}
$$

Instead, when calculating fragments with thickness distant of $50 \mathrm{~mm}$, the following formula will be used:

$$
F=\left(\frac{D_{e}}{50}\right)^{0.45}
$$

The estimation to the compressive strength $\sigma$ or UCS (Uniaxial Compressive Strength) is obtained with the following equation:

$$
\sigma=(C) I_{S(50)}=24 I_{S(50)}
$$

The value $\sigma$ is the main purpose which the point-load test follows and it is going to be compared with other values of mechanical resistance obtained by other tests. Other interesting aspect of the test is to observe the rupture mode of the fragments, finding relations between the composition of adobes, their morphology, size, fibres distribution or aggregates (See Figure 6).
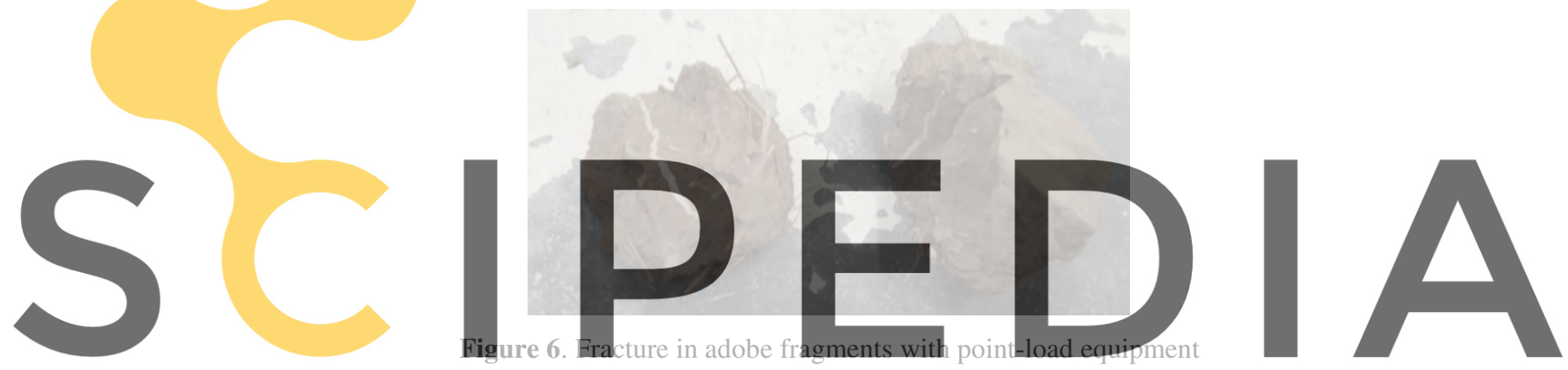

\section{Register för RFEUITIStps//www.scipedia.com to download the version without the watermark}

Figure 7 shows the classification of all the samples, including the adobes and the soils of the region, by the Unified Soil Classification System (USCS); while Table 1 shows the results of the soil classification and the grading of each one of the specimens which were subdued to the mechanical analysis. M1 and M13, the two soil samples from the clay material quarry were classified as high plasticity clays, while the adobes vary from clays of low plasticity to mods. The low plasticity was probably due to the stabilization with other materials, for example, lime was found by RXD in some specimens.

Table 1: USCS Classification of the specimens

\begin{tabular}{ccc} 
Material & \multicolumn{2}{c}{ USCS Classification } \\
\hline M2 & CL & Clay of low plasticity \\
\hline M4 & CL & Clay of low plasticity \\
\hline M5 & ML/OL & Silt / Organic silt \\
\hline M9 & ML/OL & Silt / Organic silt \\
\hline M11 & ML/OL & Silt / Organic silt \\
\hline M12 & ML/OL & Silt / Organic silt
\end{tabular}




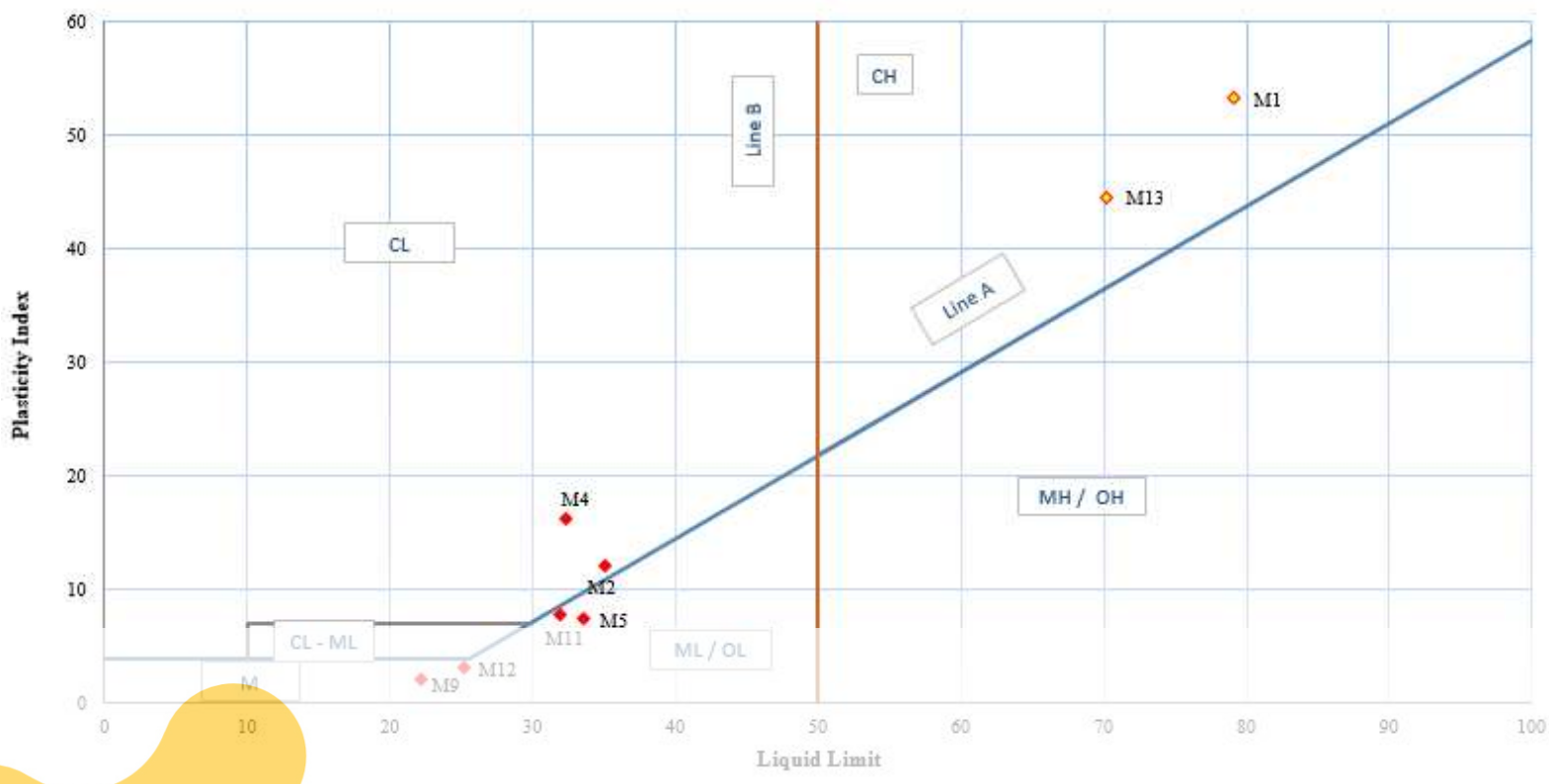

Figure 7: Plasticity graphic and position of the adobes and soil samples

The sieve analyses also permitted to separate and classify the mineral grains and vegetal fibres in the adobes. It was calculated the percentage of straw from the weight (See Ta 5) or an insignificant po diminish shrinkage, situa pable 2) Some of t hich contributes to obes did not ha
to expect the lo
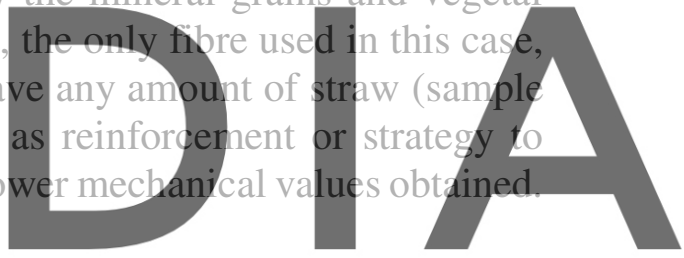

Table 3: Fibre percentage results

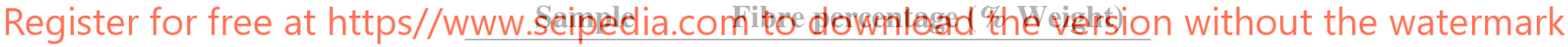

\begin{tabular}{cc} 
M2 & 0.38 \\
\hline M4 & 0.68 \\
\hline M5 & - \\
\hline M9 & 0.06 \\
\hline M11 & 0.27 \\
\hline M12 & 0.23
\end{tabular}

From the destructive tests, specifically the compressive strength, the mechanical resistance varies between $5-13 \mathrm{Kg} / \mathrm{cm} 2$, being the average of the adobe bricks $8.16 \mathrm{Kg} / \mathrm{cm} 2$. These values obtained with the compression strength test and the point-load tests are lower than values from other researches which similar characteristic cases in México [7, 16-18]. The adobe blocks of Jojutla presented low performance perhaps because of inefficient manufacture and the absence of fibre material or other stabilisers. Nevertheless, the proportion of the fibres does not seem to have a direct relation with the compressive mechanical resistance, as samples M5 and M9 had the lowest amount of straw, otherwise reached some of the highest values during the test.

The point-load test allowed to quantify some of the samples, after the compressive strength test. Because of that fragments of lower dimensions can be tested again with the equipment, it 
resulted in more number of specimens and results. The values obtained were more variable with an extended range being the average of all the adobes $3.95 \mathrm{Kg} / \mathrm{cm} 2$, lower than the compression strength results. The ratio between compressive strength and point-load values was 2.13:1, something comprehensible considering that the point-load test is designed for the analysis of different types of rocks.

Table 3: Comparative of compressive strength and point-load values results

\begin{tabular}{cccc} 
Sample & $\begin{array}{c}\text { Compressive strength } \\
\left(\mathbf{K g} / \mathbf{c m}^{2}\right)\end{array}$ & $\begin{array}{c}\text { Point-load } \boldsymbol{\sigma} \\
(\mathbf{k g} / \mathbf{c m})^{\mathbf{2}}\end{array}$ & $\mathbf{c s / \mathbf { l }}$ \\
\hline M2 & 5.97 & 3.24 & 1.84 \\
\hline M4 & 9.35 & 3.64 & 2.57 \\
\hline M5 & 12.33 & 5.78 & 2.13 \\
\hline M9 & 5.08 & 4.62 & 1.10 \\
\hline M11 & 9.13 & 3.91 & 2.33 \\
\hline M12 & 7.09 & 2.52 & 2.81 \\
\hline Mean & 8.16 & 3.95 & 2.13
\end{tabular}

The compressive strength and point-load values were compared (See Figure 8) in a graphic to observe the correlation between the two tests. Considering the compressive strength values slightly higher, most of the samples shown a lineal reciprocity, while some shown deviation,

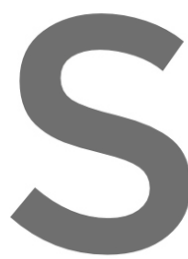
near the $2: 1$ ratio calcu
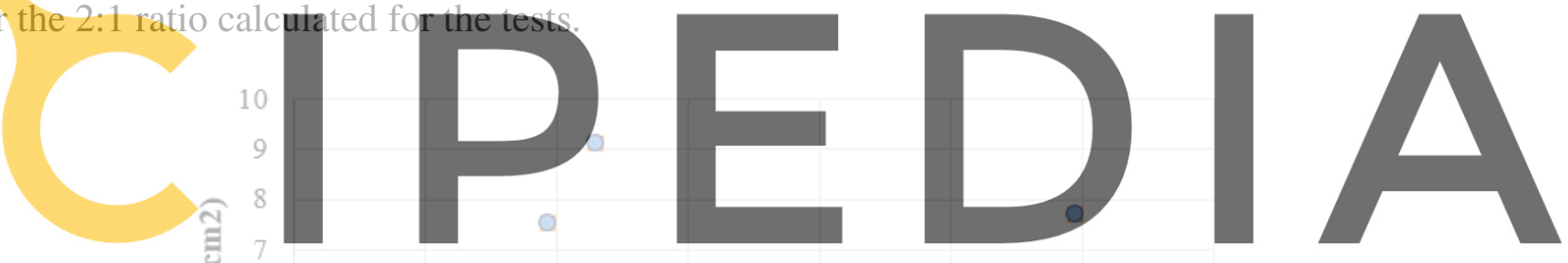

Register for free at https//5www.scipedia.com to download the version without the watermark

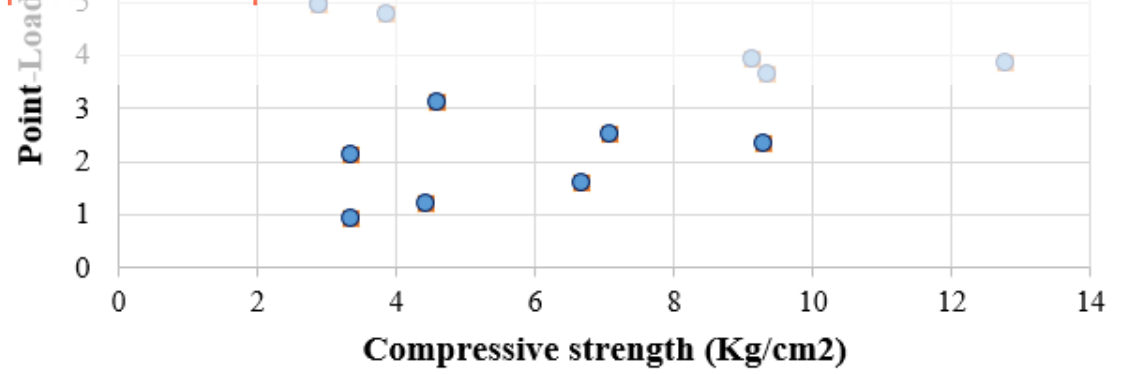

Figure 8: Correlation between the Compressive strength and the point-load tests

\footnotetext{
${ }^{2}$ The final value of the uniaxial compression resistance has been converted to kilogram per square centimetre. The original value was found in megapascals.
} 


\section{CONCLUSIONS}

While seismic affectations in monumental and vernacular architecture has been widely researched, it is very complicated to analyse study cases where the materials and buildings have been lost or demolished. Point-load test could be a useful analytic tool for measuring the mechanical resistance of patrimonial samples found in emergency situations like earthquakes or other natural hazards. The test can be performed in situ, being suitable for these cases, where the specimens are corrupted.

Point-load allows the characterisation of non-complete fragments, like the ones found in Jojutla de Juarez, Morelos. It could be a support for research works where it is impossible to access to the original constructive system. The samples could be tested in situ, which is a great benefit, nevertheless it is recommended to compare the values obtained with other mechanical resistance studies to achieve a more complete research.

The test has not been yet assessed for adobes or other earthen masonry, the standards are determined for sandstone. Nevertheless, it has been proved useful for other rocks like ignimbrites [14-15]. The comparison between compressive strength and point-load for the adobes tested shows a relation ratio compressive strength/point-load very near to $2: 1$, comprehensible considering that the point-load index $\left(\mathrm{I}_{\mathrm{S}}\right)$ was designed for sandstones [12]. More research is required as these earthen structures have not been analysed by this method and it can be useful for in-situ works.

The percentage of fine grained soils of the adobes was comprised around 15-40\%,

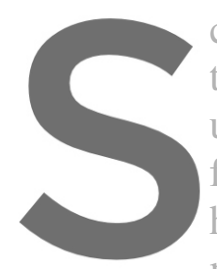
corresponding to indicative values of the tradicion
that half of the adobes had not any visible fibre
used before and re-use for new adobes so the
features of the traditional architecture of the reg
heritage, and a detrimental factor for the adobes, mechanical resistance [19]. The soil and grain size
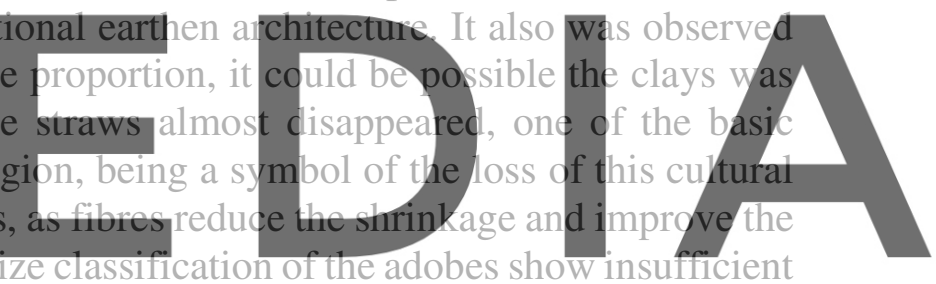
or absent amount of fibres, however there weren't found significant proportions of gravel or

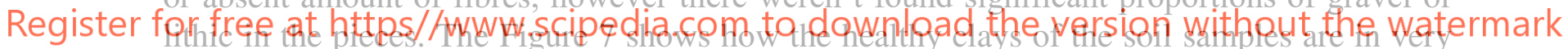

different zone of the graphic than the adobe samples. To diminish the plasticity of the adobes from high to light there couid have been some type of stabilization with local materiais, for the age of the adobes it could be lime.

Nevertheless, this low values didn't justify for itself the bad seismic behaviour of the dwellings, which were very vulnerable due to multiple factors like the lack of reinforcements and confinement of the structures, the incompatibility between the construction materials or the poor maintenance of the buildings among others, the social-economic necessity of divide the land into minor spaces to inherit descendants and so the impossibility to continue using the traditional thickness of adobe. In the study case, all these conditions converged, resulting into the loss of most of its architectural heritage and infrastructure. The adobe walls did not have any reinforcement, being this method unknown by the local population, which prefer to substitute the traditional materials for modern ones representing for them a better social status.

\section{ACKNOWLEDGEMENTS}

The authors acknowledge the Materials Laboratory "Ing. Luis Silva Ruelas" of the Faculty of Civil Engineering of the UMSNH for the equipment support, the Postgraduation coordination 
of the Faculty of Architecture of the UMSNH, the economic support given by CONACYT and CIC-UMSNH, and the technical support of B.C.E.: D. Preciado Villicaña and M. Ruiz Mendoza.

\section{REFERENCES}

[1] Servicio Sismológico Nacional. Reporte especial. Sismo de Tehuantepec (2017-09-07 23:49 $M w$ 8.2). UNAM, Grupo de trabajo del Servicio Sismológico Nacional. México: Universidad Nacional Autónoma de México, (2017).

[2] Servicio Sismológico Nacional. Reporte especial. Sismo del día 19 de Septiembre de 2017, Puebla-Morelos (M 7.1). UNAM, Grupo de trabajo del Servicio Sismológico Nacional. México: Universidad Nacional Autónoma de México, (2017).

[3] Meli Piralla, R. La ingeniería civil ante los efectos de los sismos de 2017 en los edificios patrimoniales (el equilibrio entre la autenticidad y la seguridad). In S. d. Cultura, Sismos y patrimonio cultural. Testimonios, enseñanza y desafios, 2017 y 2018 (pp. 62-81). Ciudad de México: Dirección General de Publicaciones de la Secretaría de Cultura, (2018).

[4] Blondet, M. Mitigation of Seismic Risk on Earthen Buildings. In H. Gökçekus, U. Türker, $\&$ J. W. LaMoreaux, Survival and Sustainability. Environmental Concerns in the 2 st Century (pp. 391-400). Berlín: Springer, (2011).

[5] Campos Goenaga, M. I. Las dimensiones del sismo, un año después. El Tlacuache. Órgano de difusión de la comunidad del INAH Morelos(847), 31-34, (2018).

[6] Díaz Fuentes, D., Baquedano Julià, P. A., D'Amato, M., \& Laterza, M. Preliminary Seismic Damage Assessment of Mexican Churches after. International Journal of Architectural Heritage, (2019).

[7] Guerrero Baca, L. F. Comportamiento sísmico de viviendas tradicionales de adobe, situadas en las faldas del volcán Popocatépetl, México. Gremium, 6(11), 105-118, (2019).

[8] Guerrero Baca, L. F., Meraz Quintana, L., \& Soria López, F. J. Cualidades sismorresistentes de la vivienda de adobe en las faldas del volcán Popocatépetl. In L. F. Guerrero Baca, Reutilización del patrimonio edificado en adobe (pp. 194-215). México D.F.: Casa Abierta al Tiempo: Universidad Autónoma Metropolitana, (2014).

[9] Jorquera, N. Culturas sísmicas: Estrategias vernaculares de sismorresistencia del patrimonio arquitectónico chileno. Arqutiecturas del Sur, XXXII(46), 18-29, (2014).

[10] Ríos Ramírez, G., \& Porcayo Victoriano, C. Vivienda vernácula: la transformación a través de sistemas constructivos y tipología, Hueyapan, México. In C. Neves, Z. Salcedo Gutierrez, $\&$ O. Borges Faria (Ed.), $19^{\circ}$ Seminario iberoamericano de arquitectura y construcción con tierra : conservación sostenible del paisaje, tierra y agua (pp. 516-521). San Salvador, El Salvador: FUNDASAL/PROTERRA, (2019).

[11] del Campo Alatorre, R. M., Ochoa González, G. H., \& Álvarez Partida, F. Estudio Geotécnico de la Colonia Emiliano Zapata, Jojutla, Morelos, tras los daños de los Sismos del 19 de septiembre de 2017. ITESO, Universidad Jesuita de Guadalajara, Departamento de Hábitat y Desarrollo Urbano, (2018).

[12] ASTM Standards. ASTM D5731 - 05 Standard Test Method for Determination of the Point Load Strength Index of Rock, (2007).

[13] Broch, E., \& Franklin, J. A. The point-load strenght test. International Journal of Rock Mechanics and Mining Sciences \& Geomechanics Abstracts, 9 (Issue 6), 669-676, (1972). 
[14] Navarrete Seras, M., Mártinez Molina, W., Alonso Guzmán, E. M., Arteaga Arcos, J., Chávez García, H. L., Lara Gómez, C., . . . Díaz González, N. Mathematical models applied to the physical mechanical characterization of stone materials bank Huiramba, México. In K. Esquivel Escalante, E. Elizalde Peña , \& J. A. Rodríguez Morales (Ed.), X Congreso Internacional de Ingeniería. Engineering and its applications Vol. 1. Querétaro: Universidad Autónoma de Querétaro, 252-256, (2014).

[15] Navarrete Seras, M., Martínez Molina, W., Alonso Guzmán, E., Lara Gómez, C., Artega Arcos, J., Bedolla Arroyo, J. A., \& Delgado Hernández, D. J. Rocas ígneas extrusivas e intrusivas para mampostería, método de carga puntual. XII Congreso Latinoamericano de Patología de la Construcción y XIV Congreso de Control de Calidad en la Construcción CONPAT (págs. 493-502). Cartagena de Indias, (2013)

[16] Arroyo Matus, R., Sánchez Tizapa, S., \& Catalán Quiroz, P. Caracterización experimental de las propiedades mecánicas de la mampostería de adobe del sur de México. Ingeniería, 17(3), 167-177, (2013).

[17] Cruz Farrera, F. J. Propuesta de uso de tecnologías sismorresistente de adobe para una vivienda progresiva en Cuauhtémoc, municipio de Villaflores, Chiapas. Tuxtla Gutiérrez, Chiapas, México: Universidad Autónoma de Chiapas. Facultad de Arquitectura, (2018).

[18] Ordaz Zapata, F. A. Estudio de las características mecánicas y térmicas del adobe, para su revalorización en la construcción de vivienda, en la ciudad de Torreón Coahuila, México. Torreón, Coahuila, México: Universidad Autónoma de Coahuila, Escuela de Arquitectura, Unidad Torreón, (2019).

[19] Yetgin, Ş., Çavdar, Ö., \& Çavdar, A. The effects of the fiber contents on the mechanic properties of the adobes. Construction and Building Materials (22), 222-227, (2008). 